\title{
Effects of preservation on protein extraction in four seaweed species
}

\author{
Tom Wijers $^{1}$ (D) $\cdot$ Alwin Hylkema ${ }^{1} \cdot$ Tsjippie Visser $^{1} \cdot$ Klaas Timmermans $^{2}$
}

Received: 25 March 2020 / Revised and accepted: 29 June 2020 / Published online: 13 July 2020

(C) The Author(s) 2020

\begin{abstract}
Using either freshly pulped or preserved seaweed biomass for the extraction of protein can have a great effect on the amount of protein that can be extracted. In this study, the effect of four preservation techniques (frozen, freeze-dried, and air-dried at 40 and $70^{\circ} \mathrm{C}$ ) on the protein extractability, measured as Kjeldahl nitrogen, of four seaweed species, Chondrus crispus (Rhodophyceae), Ascophyllum nodosum, Saccharina latissima (both Phaeophyceae) and Ulva lactuca (Chlorophyceae), was tested and compared with extracting freshly pulped biomass. The effect of preservation is species dependent: in all four seaweed species, a different treatment resulted in the highest protein extractability. The pellet (i.e., the non-dissolved biomass after extraction) was also analyzed as in most cases the largest part of the initial protein ended up in the pellet and not in the supernatant. Of the four species tested, freeze-dried A. nodosum yielded the highest overall protein extractability of $59.6 \%$ with a significantly increased protein content compared with the sample before extraction. For C. crispus extracting biomass air-dried at $40{ }^{\circ} \mathrm{C}$ gave the best results with a protein extractability of $50.4 \%$. Preservation had little effect on the protein extraction for S. latissima; only air-drying at 70 ${ }^{\circ} \mathrm{C}$ decreased the yield significantly. Over $70 \%$ of the initial protein ended up in the pellet for all $U$. lactuca extractions while increasing the protein content significantly. Extracting freshly pulped $U$. lactuca resulted in a $78 \%$ increase in protein content in the pellet while still containing $84.5 \%$ of the total initial total protein. These results show the importance of the right choice when selecting a preservation method and seaweed species for protein extraction. Besides the extracted protein fraction, the remaining pellet also has the potential as a source with an increased protein content.
\end{abstract}

Keywords Protein extraction $\cdot$ Preservation $\cdot$ Ulva lactuca $\cdot$ Saccharina latissima $\cdot$ Chondrus crispus $\cdot$ Ascophyllum nodosum

\section{Introduction}

The demand for high-quality protein in food and feed is bigger than ever and is expected to increase in the future (Boland et al. 2013; Henchion et al. 2017). In the 20th century, agricultural intensification provided the incurring demand, but due to increasing competition for land use between urban development, agriculture, recreation, nature preservation, and energy, traditional agriculture might no longer keep up with this demand. Moreover, the need for a protein transition from animal to plant sources is evident. It is therefore essential

Tom Wijers

tom.wijers@hvhl.nl

1 Applied research centers Food and Dairy and Delta Areas and Resources, University of Applied Sciences Van Hall Larenstein, P.O. Box 1528, 8901, BV Leeuwarden, the Netherlands

2 Department of Estuarine and Delta Systems, NIOZ Royal Netherlands Institute for Sea Research and Utrecht University, PO Box 140, 4401, NT Yerseke, the Netherlands that new sources of plant protein are explored and produced. Seaweeds are a promising source, with no need for arable land, fresh water, artificial fertilizer, and a high productivity (Černá 2011; Angell et al. 2016a; Bikker et al. 2016; Øverland et al. 2019). As protein content in seaweed varies per species, season, and location, the extraction of protein is often suggested to increase the consistency of the product and protein content of the end product (Lourenço et al. 2002; Angell et al. 2016b; Biancarosa et al. 2017).

The amount of protein that can be extracted depends on variables such as extraction method, seaweed species, and preservation technique. Preservation is often necessary, as the production of seaweed is very seasonal and the fresh biomass will quickly deteriorate after harvest. Preservation of biomass will also benefit large-scale application, as it ensures year round availability of materials (Øverland et al. 2019).

Most extraction methods described in literature (Wong and Cheung 2001a, b; Harnedy and FitzGerald 2013; Kadam et al. 2016) are based on Fleurence et al. (1995) who first extracted seaweed biomass in deionized water separating supernatant and pellet (i.e., the non-dissolved biomass after extraction) and secondly re-suspended the pellet in an alkaline solution, 
separating the supernatant and pellet, and combining the two supernatants as one final extract. However, the success of protein extraction varies, depending on the preservation technique and species used. High protein yields can be found in Phaeophyceae (brown algae), where Kadam et al. (2016) extracted $52 \%$ of the total protein from dried (at $40{ }^{\circ} \mathrm{C}$ ) Ascophyllum nodosum, and Vilg and Undeland (2017) were able to extract $60 \%$ of the total protein from frozen Saccharina latissima. Extraction from Chlorophyceae (green algae) results in lower protein yields, where Fleurence et al. (1995) could extract $27 \%$ protein from freeze-dried Ulva rigida and $36 \%$ from Ulva rotundata. The variability in the amount of protein that is extracted due to variation in species and preservation techniques makes it difficult to compare results.

Protein extraction from seaweed can be regarded successful either by extracting as much protein as possible or by leaving as much protein in the pellet and extracting mostly non-protein substances leaving a protein enriched pellet. Most literature focuses on extracting protein (Fleurence et al. 1995; Harnedy and FitzGerald 2013; Kadam et al. 2016; Vilg and Undeland 2017; Harrysson et al. 2018; Kazir et al. 2019); only a few researchers are able to extract more than $50 \%$ of the protein present in the biomass (Kadam et al. 2016; Vilg and Undeland 2017). This means that most protein remains in the pellet after extraction, but this fraction receives little attention.

A comparative study testing the same biomass with different preservation techniques, extraction techniques, and species, while looking at the protein content of both the supernatant and pellet, is missing. Therefore, it is difficult to compare results between different studies and impossible to determine what type of preservation is most suitable for a specific species. In this study, we extracted the biomass of four different seaweed species Chondrus crispus (Rhodophyceae), Ascophyllum nodosum, Saccharina latissima (both Phaeophyceae) and Ulva lactuca (Chlorophyceae) treated with four different preservation techniques (freezing, freeze drying, and air-drying at $40{ }^{\circ} \mathrm{C}$ and $70{ }^{\circ} \mathrm{C}$ ) and compared this to the extraction of freshly pulped seaweed. The composition (protein, ash content, remainder) of the obtained supernatants and pellets is compared with the composition of the freshly pulped samples before preservation and extraction.

\section{Material and methods}

\section{Biomass origin, collection, and homogenization}

Two brown seaweeds species (Phaeophyceae) were used: Ascophyllum nodosum was harvested in March 2018 from the wild in Breezanddijk, the Netherlands, and Saccharina latissima was harvested from the wild in June 2018 in Oban, Scotland. Ulva lactuca (Chlorophyceae) was harvested in May 2018 from aerated incubation tanks at the NIOZ
Seaweed Centre, Texel, the Netherlands (https://www.nioz. nl/en/research/expertise/seaweed-centre). Chondrus crispus (Rhodophyceae) was harvested in May 2018 in the wild in the Oosterschelde, the Netherlands. After harvesting, all biomass was rinsed with tap water to remove excess minerals, sand, and epiphytes and ground with a meat grinder to a homogenous pulp. For each species, a sample was frozen and stored at $-20{ }^{\circ} \mathrm{C}$ to be analyzed at a later time for protein, dry weight (DW), and ash content.

\section{Treatments}

Freshly pulped and homogenized seaweed of the four tested species was divided in five subsamples of around $200 \mathrm{~g}$. One subsample was used for extraction within $24 \mathrm{~h}$ after harvesting without any preservation. The other four treatment subsamples were preserved within $24 \mathrm{~h}$ after harvesting using the following techniques:Frozen at $-20^{\circ} \mathrm{C}$. Subsample was frozen and stored at $-20^{\circ} \mathrm{C}$. Prior to extraction, frozen biomass was defrosted by leaving it at room temperature until defrosted.

Freeze-dried. Frozen seaweed biomass was freeze-dried with a Martin Christ Alpha 2-4 LD plus freeze dryer for 72 $\mathrm{h}$. Dried biomass was stored in a dry environment at room temperature until being used for extraction.

Air-dried at $40{ }^{\circ} \mathrm{C}$ or $70^{\circ} \mathrm{C}$. Seaweed biomass was air-dried at $40{ }^{\circ} \mathrm{C}$ for $72 \mathrm{~h}$ or at $70{ }^{\circ} \mathrm{C}$ for $48 \mathrm{~h}$. Dried biomass was stored in a dry environment at room temperature until being used for extraction.

\section{Extraction methods}

For the standard extraction, a total of $3 \mathrm{~g}$ of seaweed were dissolved in demineralized water to a final volume to seaweed ratio of 30:1 (DW). For the freshly pulped samples, this was already analyzed, and calculations could be made. To aid the solubility of the seaweed protein (Fleurence et al. 1995), the $\mathrm{pH}$ was elevated by adding a $1 \mathrm{M} \mathrm{NaOH}$ stock solution to a final concentration of $0.1 \mathrm{M} \mathrm{NaOH}$. Increasing the temperature of the extraction showed an increase in extractability in preliminary extractions with the best results at $50{ }^{\circ} \mathrm{C}$, so this temperature was used for the standard extraction. The diluted biomass was mixed with a T25 Ultra-Turrax Disperser at $24000 \mathrm{rpm}$ for $5 \mathrm{~min}$ and subsequently shaken on a rotation table at $140 \mathrm{rpm}$ for $1 \mathrm{~h}$ at $50{ }^{\circ} \mathrm{C}$ after which the $\mathrm{pH}$ was measured. This solution was then centrifuged at $4500 \times g$ for $30 \mathrm{~min}$ at $20^{\circ} \mathrm{C}$, resulting in a pellet and supernatant. The pellet and the supernatant were analyzed for $\mathrm{N}, \mathrm{DW}$, and ash. A subsample of the pellet was air-dried at $105^{\circ} \mathrm{C}$ for $16 \mathrm{~h}$ prior to $\mathrm{N}$ analyses. Each extraction was performed in triplicate $(n=3)$. This resulted in fresh (freshly pulped), frozen (frozen at $-20^{\circ} \mathrm{C}$ ), freeze-dried (freeze-dried), air $40^{\circ} \mathrm{C}$, and air $70^{\circ} \mathrm{C}$. 
To test if increasing the $\mathrm{pH}$ and temperature indeed increases the protein extractability, a control extraction, further referred to as Control, was performed on the freshly pulped seaweed only. The extraction was performed as the standard extraction described above but without the addition $\mathrm{NaOH}$ and at room temperature.

A schematic overview of the extractions, measurements, and resulting treatments is shown in Fig. 1.

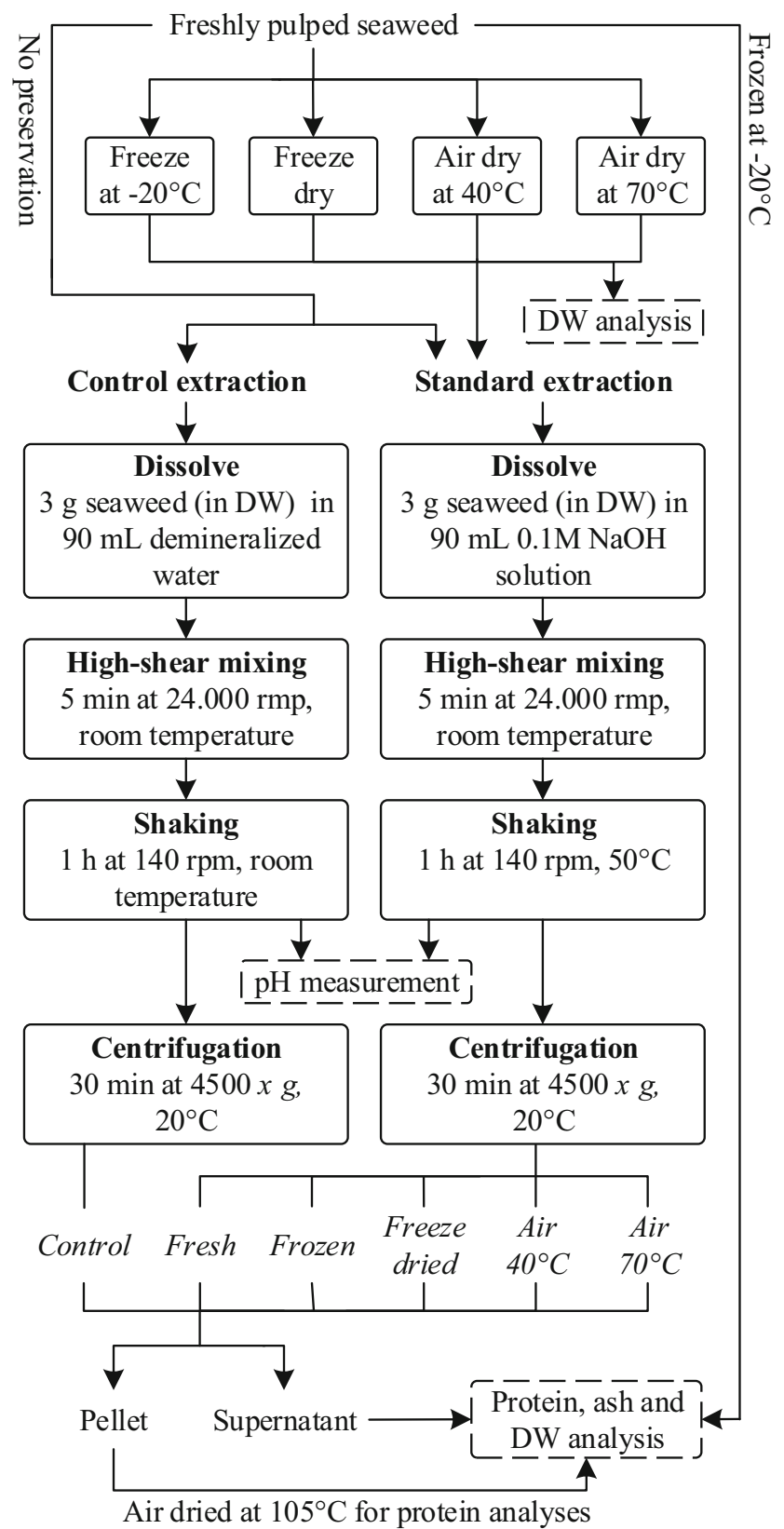

Fig. 1 Preservation and protein extraction treatments followed by the extraction sequence executed on all four seaweed species in triplicate. The 6 resulting treatments are written in italic. Dashed boxes represent analyses or measurements

\section{Protein analyses}

The total protein was measured as nitrogen, determined by the Kjeldahl method (Kjeldahl 1883). A nitrogen to protein factor of 5.0 was used to calculate the protein content according to Angell et al. (2016b).

\section{Data analysis}

The percentage of total protein in both the supernatant and pellet after extraction is calculated by dividing the amount of protein in the supernatant or pellet by the total amount of protein in the freshly pulped samples prior to extraction:

Protein (\%of total)

$$
\begin{aligned}
= & \frac{\text { Protein in supernatant or pellet }(\text { gram })}{\text { Total Protein in freshly pulped samples }(\text { gram })} \\
& \times 100
\end{aligned}
$$

IBM SPSS Statistics software was used to perform multiple one-way analysis of variance (ANOVAs) to test if preservation technique affects the $\mathrm{pH}$, ash content, protein content, and remainder of the supernatant and pellet, separate for each species. If a significant effect was found, Tukey's post-hoc tests were used to test for significant differences $(p<0.05)$ among treatments.

\section{Seaweed biomass composition}

The content of the freshly pulped samples of each species is shown in Table 1. All non-protein, non-ash contents in the DW were not analyzed. This is expressed as remainder, mainly consisting of the carbohydrates and fatty acids.

\section{Results}

\section{Total of protein in supernatant and pellet}

Preservation treatment had a significant effect on the protein extractability of all four seaweed species (Fig. 2). It differed per species which treatment resulted in the highest extractability. The standard extraction (increased $\mathrm{pH}$ at $50^{\circ} \mathrm{C}$ ) on freshly pulped seaweed had a significantly higher extractability of protein in all four species compared with the control extraction (no increased $\mathrm{pH}$ at room temperature) showing that an increased $\mathrm{pH}$ and temperature aid the extraction of protein from seaweed biomass.

For $C$. crispus, air 40 and $70{ }^{\circ} \mathrm{C}$ resulted in a protein extractability of 50.4 and $48.2 \%$, respectively, which was significantly higher than the extractability of all other treatments (Fig. 2a). All other treatments resulted in 
Table 1 Protein, ash, and remainder content of freshly pulped C. crispus, A. nodosum, S. latissima, and U. lactuca, expressed as gram per 100 gram DW

\begin{tabular}{llll}
\hline Species & $\operatorname{Protein}^{1}\left(\mathrm{~g}(100 \mathrm{~g})^{-1} \mathrm{DW}\right)$ & Ash $\left(\mathrm{g}(100 \mathrm{~g})^{-1} \mathrm{DW}\right)$ & Remainder $^{2}\left(\mathrm{~g}(100 \mathrm{~g})^{-1} \mathrm{DW}\right)$ \\
\hline C. crispus & $18.1 \pm 0.4(n=4)$ & $20.5 \pm 0.2$ & 61.4 \\
A. nodosum & $14.1 \pm 0.2(n=6)$ & $18.9 \pm 0.6$ & 67.0 \\
S. latissima & $8.0 \pm 0.6$ & $23.8 \pm 1.0$ & 68.2 \\
U. lactuca & $9.1 \pm 0.3$ & $30.3 \pm 2.6$ & 60.6
\end{tabular}

\footnotetext{
${ }^{1}$ Protein expressed as N times 5.0 according to Angell et al. (2016b). ${ }^{2}$ Remainder expressed as all non-protein, non-ash in DW. Numbers are averages \pm standard deviation ( $n=3$ except for protein of $C$. crispus and A. nodosum)
}

protein extractabilities lower than $50 \%$, and most protein remained in the pellet. Freeze drying resulted in $66.7 \%$ of the protein in the pellet, which was significantly higher than all other treatments, except the control extraction with $63.9 \%$.

For A. nodosum, almost inverse results are observed (Fig. 2b). For this species, freeze drying, freezing, and the fresh standard extraction resulted in the highest protein extractability, which were all between 55 and $60 \%$ and significantly higher than all other treatments. The control extraction resulted in $67.5 \%$ of the protein in the pellet, which was significantly higher than all other treatments. Air-drying A. nodosum

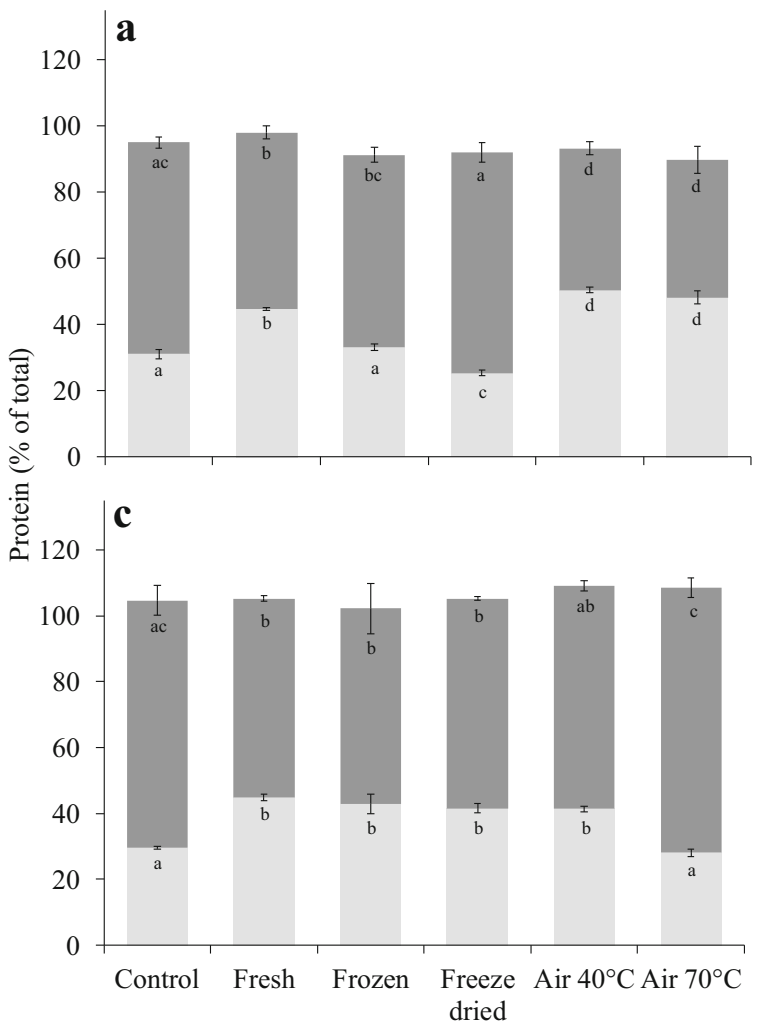

Fig. 2 The total amount of protein in supernatant (light gray bars) and pellet (dark gray bars), as a percentage of the total $\mathrm{N}$ in the freshly pulped samples after extraction (Eq. 1), of six treatments per species (a) C. crispus, (b) A. nodosum, (c) S. latissima, and (d) U. lactuca. Each resulted in intermediate results, with equal amounts of protein ending up in the pellet and the supernatant.

For S. latissima, all protein extractabilities are below 50\%, and most of the protein remain in the pellets (Fig. 2c). Most treatments yielded similar results, although air $70{ }^{\circ} \mathrm{C}$ and the control extraction resulted in significantly less protein in the extract. Air $70{ }^{\circ} \mathrm{C}$ and control resulted in a remaining protein in the pellet of 80.4 and $75.1 \%$, respectively.

For $U$. lactuca, results are similar to the results of C. crispus with the exception that air-drying the biomass resulted in low protein extractability compared with the highest values for C. crispus (Fig. 2d). Compared with the other

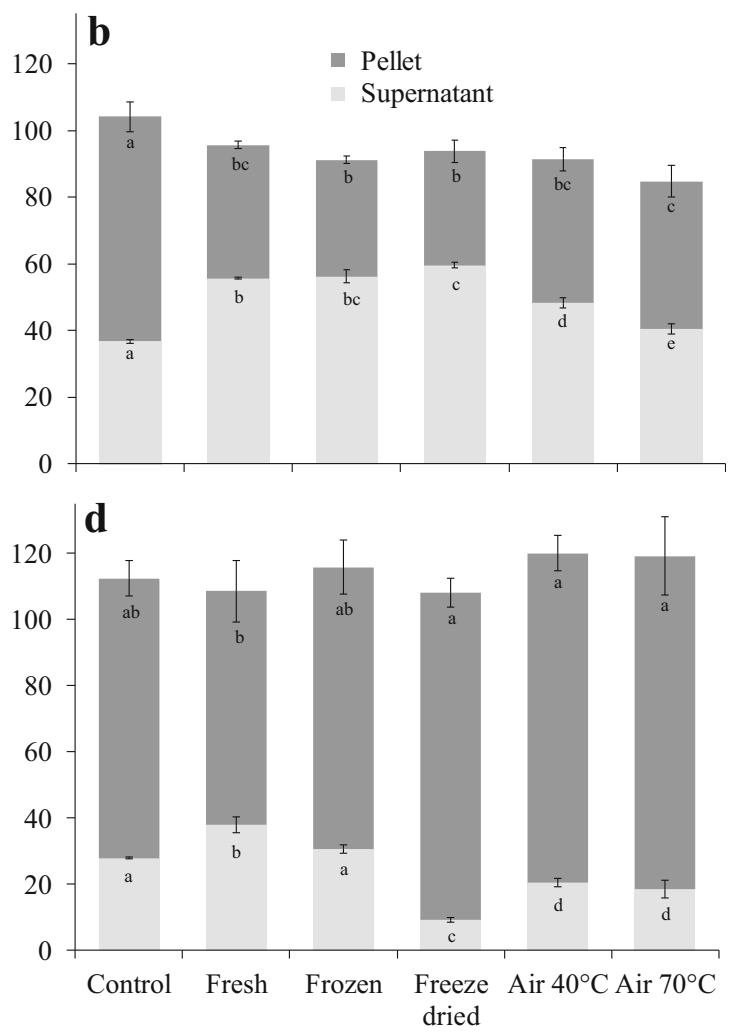

bar presents the averages $\pm \mathrm{SD}$ and $n=3$, similar letters indicate treatments for either the pellet or supernatant were not significantly different, tested with a one-way ANOVA $(p<0.05)$ 
species tested, the protein extractability of $U$. lactuca was lower. Using fresh biomass resulted in an $\mathrm{N}$ extractability of $37.9 \%$, which was significantly higher than the extractability of all other treatments. The biggest part of the protein remained in the pellet for all treatments with values of more than $70 \%$ in all preservation treatments.

\section{Protein content of supernatant and pellet}

Most treatments had a significant effect on the protein content of the pellet and supernatant, compared with the protein content of the freshly pulped samples, but the results were different for each species (Fig. 3). For C. crispus, the protein content of all supernatants was significantly different from the protein content of the freshly pulped samples (Fig. 3a). The control supernatant of $C$. crispus contained the most protein of all supernatants, with $20.5 \mathrm{~g}$ protein $(100 \mathrm{~g})^{-1} \mathrm{DW}$, a small increase compared with the $18.1 \mathrm{~g}$ protein $(100 \mathrm{~g})^{-1} \mathrm{DW}$ in freshly pulped C. crispus. All other supernatants decreased in protein content with only $10.1 \mathrm{~g}$ protein $(100 \mathrm{~g})^{-1} \mathrm{DW}$ in the supernatant of freeze-dried. The protein content of the freezedried pellet increased significantly to $21.9 \mathrm{~g}$ protein $(100 \mathrm{~g})^{-1}$ DW. This was the only pellet that showed a significant change compared with the freshly pulped C. crispus and had the highest overall protein content of all pellets and supernatants.

For A. nodosum, the protein content of the control, freezedried, and frozen supernatant, 17.2, 16.0, and $15.7 \mathrm{~g}$ protein $(100 \mathrm{~g})^{-1} \mathrm{DW}$, respectively (Fig. 3b), increase significantly compared with the protein content of the freshly pulped samples with $14.1 \mathrm{~g}$ protein $(100 \mathrm{~g})^{-1} \mathrm{DW}$. On the other hand, the protein content of all pellets decreased significantly compared with the protein content of the freshly pulped A. nodosum with only 7.8 and $8.2 \mathrm{~g}$ protein $(100 \mathrm{~g})^{-1} \mathrm{DW}$ in the pellet of frozen and freeze-dried A. nodosum. Air-drying at $70{ }^{\circ} \mathrm{C}$ resulted in a decrease in protein content for both the supernatant and pellet, to 7.6 and $7.7 \mathrm{~g}$ protein $(100 \mathrm{~g})^{-1} \mathrm{DW}$, respectively, compared with the freshly pulped $A$. nodosum, seemingly loosing protein. This can be explained by the addition of $\mathrm{NaOH}$ to aid the standard extraction, which also adds dry weight (about $10 \%$ of the total DW of the seaweed), decreasing the overall protein content in all extracted pellet and supernatant combinations.

For S. latissima, the protein content of the control, air-dried $40{ }^{\circ} \mathrm{C}$, and air-dried $70{ }^{\circ} \mathrm{C}$ supernatant, 5.1, 6.5, and $4.8 \mathrm{~g}$ protein $(100 \mathrm{~g})^{-1} \mathrm{DW}$, respectively (Fig. 3c), decreased significantly compared with the protein content of the freshly pulped samples with $8.0 \mathrm{~g}$ protein $(100 \mathrm{~g})^{-1} \mathrm{DW}$. In contrast to these supernatants, the pellets of control, air-dried $40{ }^{\circ} \mathrm{C}$, and air-dried $70^{\circ} \mathrm{C}, 11.4,9.0$, and $9.6 \mathrm{~g}$ protein $(100 \mathrm{~g})^{-1} \mathrm{DW}$, respectively, increased significantly compared with the protein content of the freshly pulped S. latissima. Fresh, frozen, and freeze-dried pellets and supernatants did not change in protein content compared with freshly pulped S. latissima.

For $U$. lactuca, the protein content of all supernatants decreased, and all pellets increased compared with the freshly pulped samples. The supernatant of freeze-dried decreased the most with $3.7 \mathrm{~g}$ protein $(100 \mathrm{~g})^{-1}$ DW compared with $9.1 \mathrm{~g}$ protein $(100 \mathrm{~g})^{-1} \mathrm{DW}$ of the freshly pulped U. lactuca. The
Fig. 3 Protein content of the supernatant (light gray bars), pellet (dark gray bars) compared with the protein content of freshly pulped samples (black dotted line) of six treatment/extraction combinations on the species (a) C. crispus, (b) A. nodosum, (c) S. latissima, and (d) U. lactuca expressed as gram per 100 gram DW. No DW samples of the fresh C. crispus supernatant were taken for which reason the protein content for the supernatant could not be determined. Each bar presents the averages $\pm \mathrm{SD}(n=3)$. Each * indicates protein content of the supernatant, and pellet was significantly different from protein content of the freshly pulped samples within each species, tested with a one-way ANOVA $(p<$ 0.05 )
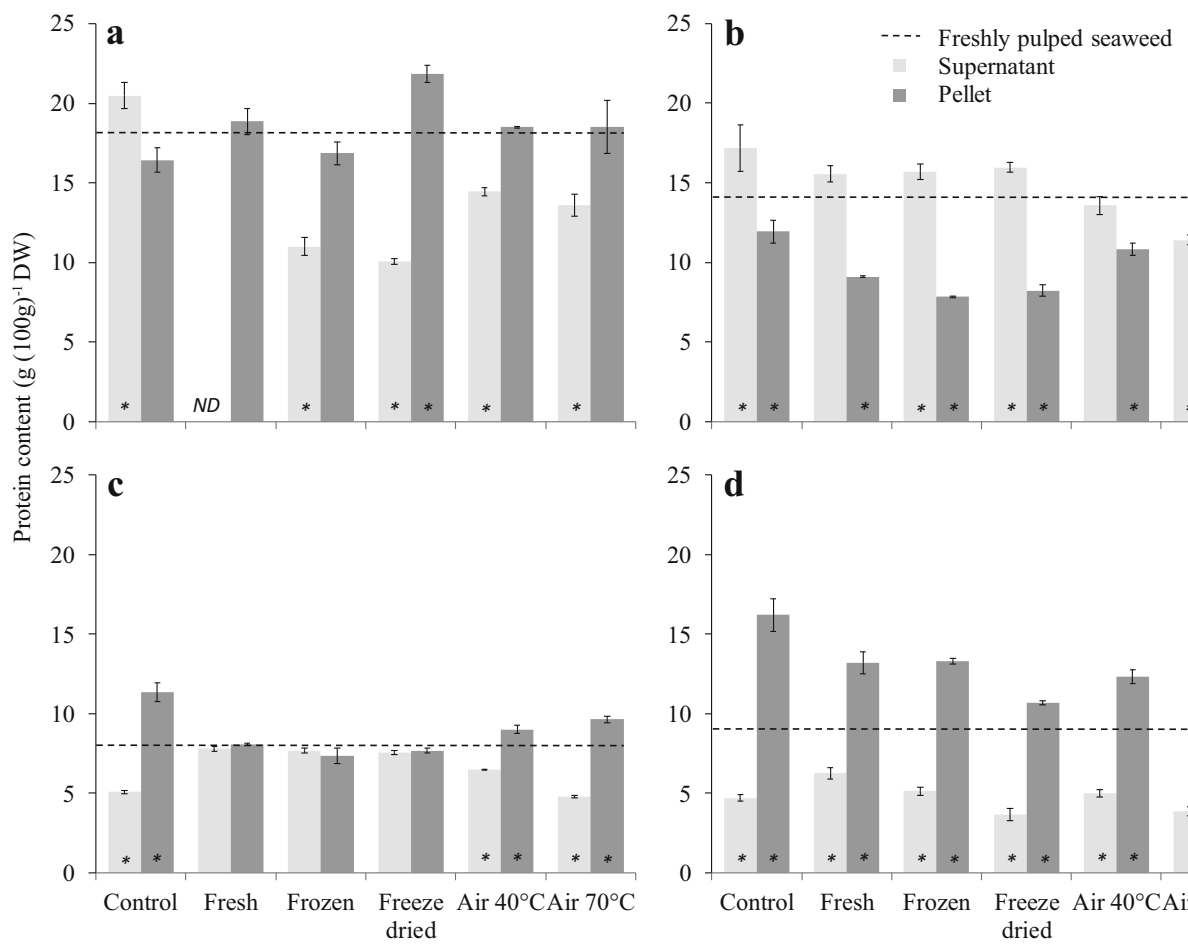
- Supernatant
Pellet
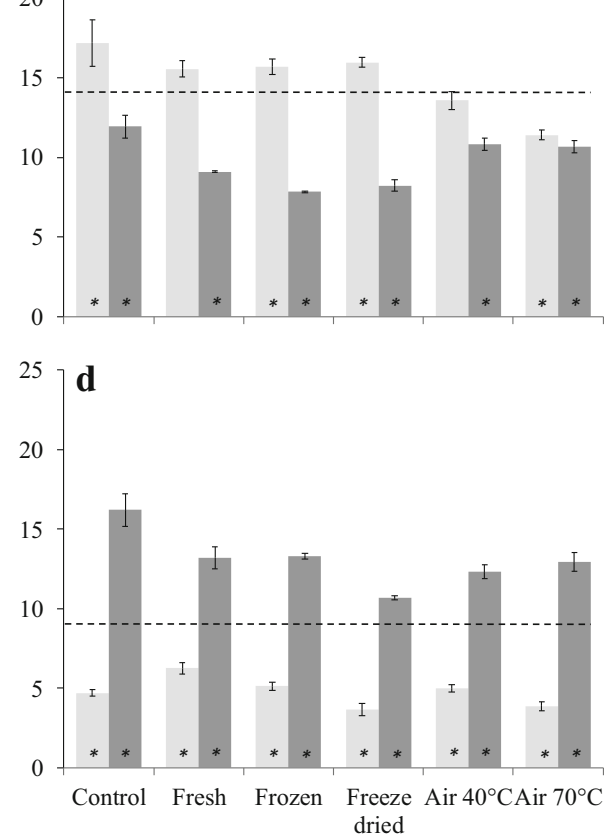
protein content of the control pellet had the highest increase compared with freshly pulped samples with $78 \%$ to $16.2 \mathrm{~g}$ protein $(100 \mathrm{~g})^{-1} \mathrm{DW}$.

\section{$\mathrm{pH}$, ash, and remainder content of supernatant and pellet}

The $\mathrm{pH}$ of all the control extracts (solution after extraction, before separating the supernatant and pellet) is significantly lower compared with the extracts of standard extraction with the addition of $\mathrm{NaOH}$ (Table 2). The average $\mathrm{pH}$ of the standard U. lactuca extracts (without the control extract), with 10.0, was low compared with A. nodosum, S. latissima, and C. crispus, $11.5,11.9$, and 11.9, respectively, suggesting that $U$. lactuca biomass contains more acid or is better capable of buffering alkaline substances.For all species, except C. crispus, the ash content of both the supernatant and pellet of the control treatments was significantly lower compared with the other treatments that were extracted with the standard extraction method (with added $\mathrm{NaOH}$ to increase $\mathrm{pH}$ ). All control and all $U$. lactuca extractions had a high ash content in the supernatants and a low ash content in the matching pellets. These differences were most notable for $U$. lactuca where the ash values in the standard extraction supernatants ranged between 56.9 and $78.6 \mathrm{~g}$ ash $(100 \mathrm{~g})^{-1} \mathrm{DW}$, and the matching pellets contained between 22.4 and $28.1 \mathrm{~g}$ ash (100 g) $)^{-1}$ DW. The protein increase in the pellet of the control treatment was partly due to the removal of ash with only $13.7 \mathrm{~g}$ ash $(100 \mathrm{~g})^{-1}$ DW remaining in the pellet after extraction. In general, the remainder content in the supernatant seemed lower compared with the matching pellet for all four species, with the biggest differences found in U. lactuca. The freeze-dried $U$. lactuca supernatant contained only contained $16.8 \mathrm{~g}$ remainder $(100 \mathrm{~g})^{-1}$, mainly due to the high ash content of $78.6 \mathrm{~g}$ ash $(100 \mathrm{~g})^{-1} \mathrm{DW}$. This seems to be a direct effect of the high ash content in the supernatant and the low ash content in the pellets. This was not observed for the other species.

\section{Discussion}

There are big differences in protein extractability, depending on the species and preservation technique used. In general, the protein extractability of fresh biomass is good when comparing with preserved biomass, but not always the best. A lower drying temperature seems to be beneficial for the protein extraction of seaweed as air-drying at $40^{\circ} \mathrm{C}$ yielded more protein in the supernatant of all four species tested compared with dried at $70{ }^{\circ} \mathrm{C}$. Besides the supernatant after extraction, some of the pellets also have potential as a new source of protein as most of the protein remained in these pellets, increasing the protein content at the same time.Most of the extraction results in this study can be compared well with extraction literature using comparable preservation techniques and seaweed species. The results of air-dried $40{ }^{\circ} \mathrm{C} \mathrm{A}$. nodosum with a protein extractability of $48.2 \%$ found here are comparable with the $51.8 \%$ extracted by Kadam et al. (2016) also using air-dried A. nodosum biomass at $40{ }^{\circ} \mathrm{C}$. For frozen S. latissima, the protein extractability of $42.9 \%$ was a little higher but still comparable with the $34 \%$ of Vilg and Undeland (2017). The protein extractability of freeze-dried $U$. lactuca biomass in this study with $9.1 \%$ was comparable with the results of Harrysson et al. (2018) who extracted roughly $10.9 \%$ of the total amino acids. The $37.9 \%$ protein extracted in fresh $U$. lactuca is slightly lower but comparable with the $43.1 \%$ found by Angell et al. (2017) with Ulva ohnoi. Angell et al. (2017) adjusted the $\mathrm{pH}$ to 12 when extracting protein; with the $0.1 \mathrm{M} \mathrm{NaOH}$ used in this study, the $\mathrm{pH}$ of our extracts remained low compared with the other species. This might also explain the lower values found here compared with Angell et al. (2017). Even when comparing literature with the same species, differences within species can have an effect on the results. The composition of the four species tested did not always correspond to the median macromolecular content of 1117 observations from seaweeds found in the wild (Fiset et al. 2019). The $U$. lactuca in this study with $9.1 \mathrm{~g}$ protein $(100 \mathrm{~g})^{-1} \mathrm{DW}$ had a relatively low protein content compared with the median value for Chlorophyceae by Fiset et al. (2019) with roughly $11.0 \mathrm{~g}$ protein $(100 \mathrm{~g})^{-1} \mathrm{DW}$, and the protein content of $C$. crispus and A. nodosum found in this study was high, compared with the median protein content of Rhodophyceae and Phaeophyceae with roughly 11.0 and $8.0 \mathrm{~g}$ protein $(100 \mathrm{~g})^{-1} \mathrm{DW}$, respectively. The protein content of $S$. latissima used in this study was comparable with the median protein content of Phaeophyceae. The ash content $U$. lactuca was in line with the median of around $34 \mathrm{~g}$ ash $(100 \mathrm{~g})^{-1} \mathrm{DW}$ for Chlorophyceae, but the other three species had a much lower content compared with the median results of their phylum. These variations in both protein and ash content might affect the amount of protein that is extracted and the content of both the supernatant and pellet. Other studies on Ulva species reported an even higher protein content values, up to $26.2 \mathrm{~g}$ protein $(100 \mathrm{~g})^{-1} \mathrm{DW}$ (Shuuluka et al. 2013; Bikker et al. 2016; Harrysson et al. 2018; Magnusson et al. 2019). Also with the higher protein values un the Ulva biomass, Bikker et al. (2016) and Magnusson et al. (2019), with slightly different extraction methods, found a comparable increase in protein content of the remaining pellet. Bikker et al. (2016) increased the protein content of $U$. lactuca by dissolving the biomass in water of $150{ }^{\circ} \mathrm{C}$ followed by enzymatic hydrolysis. The protein content measured as total amino acids increased with $66 \%$ from $26.2 \mathrm{~g}$ protein $(100 \mathrm{~g})^{-1} \mathrm{DW}$ to $40.1 \mathrm{~g}$ protein $(100 \mathrm{~g})^{-1} \mathrm{DW}$. A similar process was performed by Magnusson et al. (2019) on U. ohnoi containing $16.0 \mathrm{~g}$ protein $/ 100 \mathrm{~g}$ where the biomass was first rinsed with Milli-Q to get rid of the salts. Subsequently they removed the 
Table $2 \mathrm{pH}$ of the extracts, ash, protein, and remainder of the supernatant and pellet expressed as gram per 100 gram DW of the supernatant and pellet

\begin{tabular}{|c|c|c|c|c|c|c|c|c|}
\hline & & & Supernatant & & & Pellet & & \\
\hline Species & Treatment & $\mathrm{pH}^{2}$ & $\begin{array}{r}\text { Ash }(\mathrm{g}(100 \\
\left.\mathrm{g})^{-1} \mathrm{DW}\right)\end{array}$ & $\begin{array}{l}\text { Protein }^{3}(\mathrm{~g}(100 \\
\left.\mathrm{g})^{-1} \mathrm{DW}\right)\end{array}$ & $\begin{array}{l}\text { Remainder }^{4}(\mathrm{~g}(100 \\
\left.\mathrm{g})^{-1} \mathrm{DW}\right)\end{array}$ & $\begin{array}{l}\text { Ash (g (100 } \\
\left.\mathrm{g})^{-1} \mathrm{DW}\right)\end{array}$ & $\begin{array}{l}\text { Protein }^{3}(\mathrm{~g}(100 \\
\left.\mathrm{g})^{-1} \mathrm{DW}\right)\end{array}$ & $\begin{array}{l}\text { Remainder }^{4}(\mathrm{~g}(100 \\
\left.\mathrm{g})^{-1} \mathrm{DW}\right)\end{array}$ \\
\hline \multirow[t]{6}{*}{ C. crispus } & Control & $\begin{array}{l}6.7 \pm \\
0.0^{\mathrm{a}}\end{array}$ & $29.9 \pm 0.2^{\mathrm{a}}$ & $20.5 \pm 0.8^{\mathrm{a}}$ & $49.7 \pm 1.0^{\mathrm{a}}$ & $18.7 \pm 0.2^{\mathrm{a}}$ & $16.4 \pm 0.8^{\mathrm{a}}$ & $64.9 \pm 0.9^{\mathrm{a}}$ \\
\hline & Fresh $^{1}$ & $\begin{array}{c}11.9 \pm \\
0.0^{\mathrm{bc}}\end{array}$ & - & - & - & $33.6 \pm 0.3^{\mathrm{b}}$ & $18.9 \pm 0.8^{\mathrm{a}}$ & $47.5 \pm 0.8^{\mathrm{bc}}$ \\
\hline & Frozen & $\begin{array}{c}11.9 \pm \\
0.1^{\mathrm{bc}}\end{array}$ & $34.1 \pm 2.0^{\mathrm{ab}}$ & $11.0 \pm 0.6^{\mathrm{b}}$ & $54.9 \pm 2.5^{\mathrm{a}}$ & $30.9 \pm 0.2^{\mathrm{b}}$ & $16.9 \pm 0.7^{\mathrm{a}}$ & $52.2 \pm 0.5^{\mathrm{c}}$ \\
\hline & Freeze-dried & $\begin{array}{r}11.9 \pm \\
0.0^{\mathrm{c}}\end{array}$ & $37.7 \pm 0.4^{\mathrm{bc}}$ & $10.1 \pm 0.2^{\mathrm{b}}$ & $52.3 \pm 0.5^{\mathrm{a}}$ & $33.7 \pm 0.5^{\mathrm{b}}$ & $21.9 \pm 0.5^{\mathrm{b}}$ & $44.5 \pm 1.0^{\mathrm{b}}$ \\
\hline & Air $40{ }^{\circ} \mathrm{C}$ & $\begin{array}{r}11.8 \pm \\
0.0^{\mathrm{b}}\end{array}$ & $39.4 \pm 0.3^{\mathrm{c}}$ & $14.4 \pm 0.3^{\mathrm{c}}$ & $46.1 \pm 0.5^{\mathrm{a}}$ & $30.9 \pm 0.4^{\mathrm{b}}$ & $18.5 \pm 0.1^{\mathrm{a}}$ & $50.6 \pm 0.5^{\mathrm{c}}$ \\
\hline & Air $70{ }^{\circ} \mathrm{C}$ & $\begin{array}{c}11.8 \pm \\
0.1^{\mathrm{bc}}\end{array}$ & $33.2 \pm 3.5^{\mathrm{ab}}$ & $13.6 \pm 0.7^{\mathrm{c}}$ & $53.3 \pm 3.8^{\mathrm{a}}$ & $18.8 \pm 2.7^{\mathrm{a}}$ & $18.5 \pm 1.7^{\mathrm{a}}$ & $62.7 \pm 3.0^{\mathrm{a}}$ \\
\hline \multirow[t]{6}{*}{ A. nodosum } & Control & $\begin{array}{l}6.0 \pm \\
0.1^{\mathrm{a}}\end{array}$ & $19.9 \pm 2.2^{\mathrm{a}}$ & $17.2 \pm 1.5^{\mathrm{a}}$ & $62.9 \pm 3.6^{\mathrm{a}}$ & $16.0 \pm 0.0^{\mathrm{a}}$ & $11.9 \pm 0.7^{\mathrm{a}}$ & $72.1 \pm 0.7^{\mathrm{a}}$ \\
\hline & Fresh & $\begin{array}{r}11.6 \pm \\
0.0^{\mathrm{b}}\end{array}$ & $40.2 \pm 3.8^{\mathrm{b}}$ & $15.6 \pm 0.5^{\mathrm{ab}}$ & $44.3 \pm 3.8^{\mathrm{b}}$ & $30.1 \pm 1.3^{\mathrm{b}}$ & $9.1 \pm 0.1^{\mathrm{bc}}$ & $60.8 \pm 1.2^{\mathrm{b}}$ \\
\hline & Frozen & $\begin{array}{c}11.4 \pm \\
0.1^{\mathrm{bc}}\end{array}$ & $41.5 \pm 2.7^{\mathrm{b}}$ & $15.7 \pm 0.5^{\mathrm{a}}$ & $42.9 \pm 2.6^{\mathrm{b}}$ & $34.7 \pm 0.9^{\mathrm{bc}}$ & $7.8 \pm 0.1^{\mathrm{c}}$ & $57.4 \pm 1.0^{\text {bc }}$ \\
\hline & Freeze-dried & $\begin{array}{c}11.5 \pm \\
0.0^{\mathrm{bc}}\end{array}$ & $41.0 \pm 3.0^{\mathrm{b}}$ & $16.0 \pm 0.3^{\mathrm{a}}$ & $43.0 \pm 3.2^{\mathrm{b}}$ & $31.9 \pm 2.6^{\mathrm{b}}$ & $8.2 \pm 0.4^{\mathrm{bc}}$ & $59.9 \pm 2.4^{\mathrm{b}}$ \\
\hline & $\operatorname{Air} 40^{\circ} \mathrm{C}$ & $\begin{array}{r}11.4 \pm \\
0.1^{\mathrm{c}}\end{array}$ & $46.0 \pm 2.1^{\mathrm{b}}$ & $13.6 \pm 0.6^{\mathrm{b}}$ & $40.4 \pm 2.6^{\mathrm{b}}$ & $40.5 \pm 2.5^{\mathrm{c}}$ & $10.8 \pm 0.4^{\mathrm{d}}$ & $48.7 \pm 2.3^{\mathrm{d}}$ \\
\hline & Air $70{ }^{\circ} \mathrm{C}$ & $\begin{array}{r}11.4 \pm \\
0.0^{\mathrm{bc}}\end{array}$ & $39.7 \pm 3.1^{\mathrm{b}}$ & $11.4 \pm 0.3^{\mathrm{c}}$ & $48.9 \pm 2.8^{\mathrm{b}}$ & $39.0 \pm 3.5^{\mathrm{c}}$ & $10.7 \pm 0.4^{\mathrm{d}}$ & $50.3 \pm 3.2^{\text {cd }}$ \\
\hline \multirow[t]{6}{*}{ S. latissima } & Control & $\begin{array}{c}6.3 \pm \\
0.1^{\mathrm{a}}\end{array}$ & $31.5 \pm 0.2^{\mathrm{a}}$ & $5.1 \pm 0.1^{\mathrm{a}}$ & $63.4 \pm 0.2^{\mathrm{a}}$ & $19.0 \pm 0.7^{\mathrm{a}}$ & $11.4 \pm 0.6^{\mathrm{a}}$ & $69.7 \pm 0.7^{\mathrm{a}}$ \\
\hline & Fresh & $\begin{array}{r}12.8 \pm \\
0.1^{\mathrm{b}}\end{array}$ & $38.3 \pm 1.0^{\mathrm{b}}$ & $7.8 \pm 0.1^{b}$ & $53.9 \pm 1.1^{\text {bd }}$ & $33.9 \pm 0.6^{\mathrm{bc}}$ & $8.1 \pm 0.1^{\mathrm{b}}$ & $58.0 \pm 0.7^{\mathrm{b}}$ \\
\hline & Frozen & $\begin{array}{r}11.7 \pm \\
0.0^{\mathrm{c}}\end{array}$ & $39.2 \pm 1.1^{\mathrm{b}}$ & $7.7 \pm 0.2^{\mathrm{b}}$ & $53.1 \pm 0.9^{\mathrm{bc}}$ & $33.7 \pm 0.7^{\mathrm{bc}}$ & $7.4 \pm 0.5^{\mathrm{b}}$ & $58.9 \pm 0.7^{\mathrm{b}}$ \\
\hline & Freeze-dried & $\begin{array}{r}11.7 \pm \\
0.0^{\mathrm{c}}\end{array}$ & $36.8 \pm 1.1^{\mathrm{b}}$ & $7.6 \pm 0.1^{b}$ & $55.6 \pm 1.2^{\mathrm{d}}$ & $33.3 \pm 1.2^{\mathrm{c}}$ & $7.7 \pm 0.1^{b}$ & $59.0 \pm 1.3^{\mathrm{b}}$ \\
\hline & Air $40{ }^{\circ} \mathrm{C}$ & $\begin{array}{r}11.7 \pm \\
0.0^{\mathrm{c}}\end{array}$ & $42.3 \pm 0.5^{\mathrm{c}}$ & $6.5 \pm 0.0^{\mathrm{c}}$ & $51.3 \pm 0.5^{\mathrm{c}}$ & $28.8 \pm 0.9^{\mathrm{d}}$ & $9.0 \pm 0.2^{\mathrm{c}}$ & $62.2 \pm 0.7^{\mathrm{c}}$ \\
\hline & Air $70{ }^{\circ} \mathrm{C}$ & $\begin{array}{r}11.7 \pm \\
0.0^{\mathrm{c}}\end{array}$ & $42.9 \pm 0.1^{\mathrm{c}}$ & $4.8 \pm 0.1^{\mathrm{a}}$ & $52.3 \pm 0.1^{\mathrm{bc}}$ & $32.6 \pm 0.4^{\mathrm{bc}}$ & $9.6 \pm 0.2^{\mathrm{c}}$ & $57.7 \pm 0.4^{\mathrm{b}}$ \\
\hline \multirow[t]{6}{*}{ U. lactuca } & Control & $\begin{array}{l}5.6 \pm \\
0.1^{\mathrm{a}}\end{array}$ & $47.9 \pm 1.3^{\mathrm{a}}$ & $4.7 \pm 0.2^{\mathrm{a}}$ & $47.4 \pm 1.4^{\mathrm{a}}$ & $13.7 \pm 0.4^{\mathrm{a}}$ & $16.2 \pm 1.0^{\mathrm{a}}$ & $70.1 \pm 0.9^{\mathrm{a}}$ \\
\hline & Fresh & $\begin{array}{r}10.8 \pm \\
0.1^{\mathrm{b}}\end{array}$ & $56.9 \pm 0.4^{\mathrm{b}}$ & $6.3 \pm 0.3^{\mathrm{b}}$ & $36.8 \pm 0.4^{\mathrm{b}}$ & $22.6 \pm 1.0^{\mathrm{b}}$ & $13.2 \pm 0.7^{\mathrm{b}}$ & $64.2 \pm 1.3^{\mathrm{b}}$ \\
\hline & Frozen & $\begin{array}{c}9.8 \pm \\
0.1^{\mathrm{cd}}\end{array}$ & $57.6 \pm 0.6^{\mathrm{b}}$ & $5.1 \pm 0.3^{\mathrm{a}}$ & $37.3 \pm 0.6^{\mathrm{b}}$ & $22.4 \pm 0.3^{\mathrm{b}}$ & $13.3 \pm 0.2^{\mathrm{b}}$ & $64.3 \pm 0.5^{\mathrm{b}}$ \\
\hline & Freeze-dried & $\begin{array}{r}10.0 \pm \\
0.1^{\mathrm{d}}\end{array}$ & $78.6 \pm 3.4^{\mathrm{c}}$ & $3.8 \pm 0.6^{\mathrm{c}}$ & $16.8 \pm 1.7^{\mathrm{c}}$ & $28.1 \pm 0.7^{\mathrm{c}}$ & $10.7 \pm 0.1^{\mathrm{c}}$ & $61.2 \pm 0.6^{\mathrm{cd}}$ \\
\hline & Air $40^{\circ} \mathrm{C}$ & $\begin{array}{l}9.7 \pm \\
0.0^{\mathrm{c}}\end{array}$ & $68.0 \pm 2.1^{\mathrm{d}}$ & $5.0 \pm 0.2^{\mathrm{a}}$ & $27.0 \pm 2.3^{\mathrm{d}}$ & $26.6 \pm 1.1^{\mathrm{c}}$ & $12.3 \pm 0.4^{\mathrm{b}}$ & $61.0 \pm 1.4^{\mathrm{cd}}$ \\
\hline & Air $70{ }^{\circ} \mathrm{C}$ & $\begin{array}{l}9.7 \pm \\
0.3^{\mathrm{c}}\end{array}$ & $65.9 \pm 3.2^{\mathrm{d}}$ & $3.9 \pm 0.3^{\mathrm{c}}$ & $30.2 \pm 2.9^{\mathrm{d}}$ & $24.2 \pm 0.5^{\mathrm{b}}$ & $12.9 \pm 0.6^{\mathrm{b}}$ & $62.8 \pm 0.5^{\mathrm{bd}}$ \\
\hline
\end{tabular}

${ }^{1}$ No DW samples of the fresh C. crispus supernatant were analyzed so ash $\%, \mathrm{~N} \%$, and remainder could not be determined.

${ }^{2}$ Measured in the extract after extraction and before separating the supernatant and pellet.

${ }^{3}$ Protein expressed as N times 5.0 according to Angell et al. (2016b).

${ }^{4}$ Remainder expressed as all non-ash, non-protein in DW.

Numbers are averages \pm SD $(n=3)$, similar letters indicate treatments were not significantly different within each species, tested with a one-way ANOVA $(p<0.05)$ 
ulvans, a sulfated polysaccharide commonly present in Chlorophyceae, leaving an enriched pellet with a protein increase of $95 \%$ with a final concentration of $31.5 \mathrm{~g}$ protein $(100$ $\mathrm{g})^{-1}$ DW. Even though methods were slightly different and the protein content in the extracted Ulva varied, both results are in range with the $78 \%$ protein increase found in this study with U. lactuca that only contained $9.1 \mathrm{~g}$ protein $(100 \mathrm{~g})^{-1} \mathrm{DW}$. These results show that, for Ulva species, simply extracting the biomass with water is a promising method for obtaining a pellet with increased protein content. The amount of protein is not always clear if the supernatant or the pellet is most suitable as a protein product. Extracting protein from A. nodosum resulted in the highest extractability and an increased protein content in the supernatant compared with the freshly pulped samples so this supernatant seems suitable. In contrast to protein in a solid pellet, protein in the liquid supernatant is still relatively easy to process to further increase the protein content with techniques like membrane filtration (Kadam et al. 2016) or pH-assisted precipitation (Vilg and Undeland 2017). The downsides of further processing are increasing costs and less product. With each processing step, a portion of the protein does not end up in the final product, decreasing the overall yield. Most of the pellets after extraction, as especially seen with $U$. lactuca, contain a large part of the protein fraction while increasing the protein content making them more usable as a protein product compared with their corresponding supernatants. With fewer processing steps, the costs of a pellet will stay low compared with the extra processing steps of the supernatant, but it is harder to increase the protein content of the product any further. Either the supernatant or pellet can be more suitable, depending on the extracted amount of protein, the protein content, and specific demands of the product regarding price and protein content.This study makes it easier to compare protein extraction results with different preservation methods and species, but this is just one part of the protein extraction process. Studies further optimizing and standardizing either the extraction of protein or upgrading the protein content of the pellet are needed. When extracting protein from a species that is not tested in this study, it is recommended to test the effect of preservation first as each species in this study, even the two brown seaweeds, had different optimal preservation techniques. Industries and researchers should be aware that choosing the proper preservation technique for a specific seaweed species can make a big difference in the amount of protein extracted to the supernatant or left in the pellet.

Acknowledgments The authors thank Tristan Speerstra and Jeroen Spruit for helping with the experiments and measurements and Dirk Jan Vos from Danvos B.V. for advice. Experiments are conducted within the scope of the ZEEVIVO project (seaweed in fish feed), partially funded by SIA, part of the Netherlands Organization for Scientific Research (NWO).
Open Access This article is distributed under the terms of the Creative Commons Attribution 4.0 International License (http:// creativecommons.org/licenses/by/4.0/), which permits unrestricted use, distribution, and reproduction in any medium, provided you give appropriate credit to the original author(s) and the source, provide a link to the Creative Commons license and indicate if changes were made.

\section{References}

Angell AR, Angell SF, de Nys R, Paul NA (2016a) Seaweed as a protein source for mono-gastric livestock. Trends Food Sci Technol 54:74 84

Angell AR, Mata L, de Nys R, Paul NA (2016b) The protein content of seaweeds: a universal nitrogen-to-protein conversion factor of five. $\mathrm{J}$ Appl Phycol 28:511-524

Angell AR, Paul NA, de Nys R (2017) A comparison of protocols for isolating and concentrating protein from the green seaweed Ulva ohnoi. J Appl Phycol 29:1011-1026

Biancarosa I, Espe M, Bruckner CG, Heesch S, Liland N, Waagbø R, Torstensen B, Lock EJ (2017) Amino acid composition, protein content, and nitrogen-to-protein conversion factors of 21 seaweed species from Norwegian waters. J Appl Phycol 29:1001-1009

Bikker P, van Krimpen MM, van Wikselaar P, Houweling-Tan B, Scaccia N, van Hal JW, Huijgen WJ, Cone JW, López-Contreras AM (2016) Biorefinery of the green seaweed Ulva lactuca to produce animal feed, chemicals and biofuels. J Appl Phycol 28:35113525

Boland MJ, Rae AN, Vereijken JM, Meuwissen MPM, Fischer ARH, van Boekel MAJS, Rutherfurd SM, Gruppen H, Moughan PJ, Hendriks WH (2013) The future supply of animal-derived protein for human consumption. Trends Food Sci Technol 29:62-73

Černá M (2011) Seaweed proteins and amino acids as nutraceuticals. Adv Food Nutr Res 64:297-312

Fiset C, Irwin AJ, Finkel ZV (2019) The macromolecular composition of non-calcified marine macroalgae. J Phycol 55:1361-1369

Fleurence J, Le Coeur C, Mabeau S, Maurice M, Landrein A (1995) Comparison of different extractive procedures for proteins from the edible seaweeds Ulva rigida and Ulva rotundata. J Appl Phycol 7:577-582

Harnedy PA, FitzGerald RJ (2013) Extraction of protein from the macroalga Palmaria palmata. LWT Food Sci Technol 51:375-382

Harrysson H, Hayes M, Eimer F, Carlsson N-G, Toth GB, Undeland I (2018) Production of protein extracts from Swedish red, green, and brown seaweeds, Porphyra umbilicalis Kützing, Ulva lactuca Linnaeus, and Saccharina latissima (Linnaeus) J. V. Lamouroux using three different methods. J Appl Phycol 30:3565-3580

Henchion M, Hayes M, Mullen A, Fenelon M, Tiwari B (2017) Future protein supply and demand: strategies and factors influencing a sustainable equilibrium. Foods 6:53

Kadam SU, Avarez C, Tiwari BK, O’Donnell CP (2016) Extraction and characterization of protein from Irish brown seaweed Ascophyllum nodosum. Food Res Int 99:1021-1027

Kazir M, Abuhassira Y, Robin A, Nahor O, Luo J, Israel A, Golberg A, Livney YD (2019) Extraction of proteins from two marine macroalgae, Ulva sp. and Gracilaria sp., for food application, and evaluating digestibility, amino acid composition and antioxidant properties of the protein concentrates. Food Hydrocoll 87:194-203

Kjeldahl J (1883) Neue Methode zur Bestimmung des Stickstoffs in organischen Körpern. Z Anal Chem 22:366-382

Lourenço SO, Barbarino E, De-Paula JC, Prereira LOS, Marquez UML (2002) Amino acid composition, protein content and calculation of nitrogen-to-protein conversion factors for 19 tropical seaweeds. Phycol Res 50:233-241 
Magnusson M, Glasson CRK, Vucko MJ, Angell A, Neoh TL, de Nys R (2019) Enrichment processes for the production of high-protein feed from the green seaweed Ulva ohnoi. Algal Res 41:101555

Øverland M, Mydland LT, Skrede A (2019) Marine macroalgae as sources of protein and bioactive compounds in feed for monogastric animals. J Sci Food Agric 99:13-24

Shuuluka D, Bolton JJ, Anderson RJ (2013) Protein content, amino acid composition and nitrogen-to-protein conversion factors of Ulva rigida and Ulva capensis from natural populations and Ulva lactuca from an aquaculture system, in South Africa. J Appl Phycol 25:677685

Vilg JV, Undeland I (2017) pH-driven solubilization and isoelectric precipitation of proteins from the brown seaweed Saccharina latissima - effects of osmotic shock, water volume and temperature. J Appl Phycol 29:585-593

Wong K, Cheung PC (2001a) Influence of drying treatment on three Sargassum species 2. Protein extractabitlity, in vitro protein digestibility and amino acid profile of protein concentrates. J Appl Phycol 13:51-58

Wong KH, Cheung PCK (2001b) Nutritional evaluation of some subtropical red and green seaweeds Part II. In vitro protein digestibility and amino acid profiles of protein concentrates. Food Chem 72:11-17

Publisher's note Springer Nature remains neutral with regard to jurisdictional claims in published maps and institutional affiliations. 